\title{
Pengembangan Media Permainan Engklek Pada Materi Alat Gerak Manusia Untuk Siswa Kelas V (Lima) Sekolah Dasar
}

\author{
Eyan $^{1 *}$, Syafruddin', Baiq Niswatul Khair ${ }^{1}$ \\ Universitas Mataram, Mataram, Indonesia \\ "Corresponding author: eyan071997@gmail.com
}

\begin{abstract}
Abstrak: Tujuan dari penelitian ini adalah menghasilkan media permainan engklek untuk materi alat gerak manusia kelas $V$ SD. Metode penelitian yang digunakan adalah metode penelitian dan pengembangan dengan menggunakan model 4D yang merupakan singkatan dari Define, Design, Development and Dissemination. Subjek penelitian adalah 6 orang siswa kelas V dari SDN Pemasah, dengan spesifikasi 2 siswa berkemampuan tinggi, 2 siswa berkemampuan sedang, dan 2 siswa berkemampuan rendah. Adapun teknik pengumpulan data yang digunakan dalam penelitin ini adalah observasi, angket, dokumentasi, dan tes dalam bentuk uraian. Instrumen angket disebarkan kepada ahli media, ahli materi, dan ahli pembelajaran untuk untuk mendapatkan hasil validasi dan angket yang disebarkan kepada siswa digunakan untuk memperoleh data respon siswa. Dan untuk teknik analisis data dalam penilaian media permainan engklek ini menggunakan analisis deskriptif kualitatif dan analisis deskriptif kuantitatif dengan menggunakan skala likert. Hasil validasi dari ketiga validator memenuhi kategori valid dengan perolehan skor rata-rata dari dari ahli media 4,27 dengan kriteria "sangat baik", dari ahli materi 3,7 dengan kriteria "baik", dan dari ahli pembelajaran 4,46 dengan kriteria "sangat baik". Adapun respon keenam siswa saat uji coba terbatas yaitu 4,47 dengan kriteria "sangat baik". Hal ini menujukkan bahwa media permainan engklek dikategorikan layak untuk digunakan dalam proses pembelajaran.
\end{abstract}

Kata Kunci: media pembelajaran, media permainan engklek

Abstract: The purpose of this research is to produce crank game media for the material of human movement tool for fifth grade elementary school students. The research method used is a research and development method using the 4D model which stands for Define, Design, Development and Dissemination. The research subjects were 6 grade $V$ students from SDN Pemasah, with specifications of 2 high-ability students, 2 moderate-ability students, and 2 low-ability students. The data collection techniques used in this research were observation, questionnaires, documentation, and internal tests. form description. The questionnaire instrument was distributed to media experts, material experts, and learning experts to obtain validation results and questionnaires distributed to students were used to obtain student response data. And for data analysis techniques in the assessment of this crank game media using qualitative descriptive analysis and quantitative descriptive analysis using a Likert scale. The results of the validation of the three validators met the valid category with the acquisition of an average score from media experts 4.27 with the criteria "very good", from material experts 3.7 with "good" criteria, and from learning experts 4.46 with the criteria "very good". The response of the six students during the limited trial was 4.47 with the criteria "very good". This shows that the crank game media is categorized as suitable for use in the learning process.

Keywords: learning media, engklek game media

\section{PENDAHULUAN}

Belajar merupakan suatu kegiatan yang dilakukan oleh manusia selama masa hidupnya dengan memperoleh perubahan dalam aspek kognitif, psikomotorik, dan afektif. Menurut Pane 
\& Dasopang (2017) belajar merupakan proses perubahan tingkah laku dan perubahan pemahaman yang pada mulanya seorang anak tidak dibekali dengan potensi fitrah, kemudian dengan terjadinya proses belajar maka tingkah laku dan pemahaman anak tersebut akan akan semakin bertambah. Lefudin (2017) juga mengemukakan bahwa, belajar adalah proses perubahan perilaku yang mencakup pengetahuan, pemahaman, keterampilan, sikap, dan sebagainya yang merupakan akibat dari adanya interaksi antara individu dengan lingkungannya. Interaksi antar individu yang terjadi pada siswa dapat terus berlangsung selamadi sekolah dan di rumah.

Interaksi di sekolah biasanya terjadi pada saat belajar, melakukan diskusi dan bermain. Adapun interaksi tersebut seringkali berlanjut hingga di luar sekolah. Hal tersebut senada dengan yang diungkapkan oleh Ermiana, Witono, \& Khair (2019) yang mengatakan bahwa proses pembelajaran yang mencakup interaksi antar siswa tidak hanya terjadi di dalam kelas namun dapat juga terjadi di mana saja baik di rumah, perpustakaan, laboratorium, taman, asalkan terjadi proses transformasi informasi.

Untuk dapat menunjang pembelajaran yang berkualitas dan menarik dalam proses pembelajaran yang dilakukan di dalam maupun di luar kelas maka dapat digunakan media pembelajaran. Media pembelajaran merupakan alat bantu dalam proses belajar mengajar untuk merangsang pikiran, perasaan, perhatian dan kemampuan atau keterampilan pembelajar sehingga dapat mendorong terjadinya proses belajar (Tafonao, 2018). Sedangkan menurut Jalinus \& Ambiyar (2016) media pembelajaran merupakan segala sesuatu yang menyangkut software dan hardware yang dapat digunakan untuk menyampaikan isi materi ajar dari sumber pembelajaran ke peserta didik (individu atau kelompok), yang dapat merangsang pikiran, perasaan, perhatian, dan minat pembelajar sedemikian rupa sehingga proses pembelajaran (di dalam/ di luar kelas) menjadi lebih efektif.

Ada tiga syarat yang harus diperhatikan dalam mengembangkan sebuah media pembelajaran diantaranya: 1) Syarat edukatif, 2) Syarat teknis, dan 3) Syarat estetika (Japar \& Lakshita, 2019). Dengan terpenuhimya ketiga syarat tersebut, maka manfaat dari penggunaan media pembelajaran dapat dirasakan selama proses pembelajaran. Selain penjelasan di atas, adapun peranan media pembelajaran dalam proses belajar mengajar diantaranya: 1). Dapat menghindari terjadinya verbalisme. 2). Membangkitkan minat atau motivasi. 3). Menarik perhatian. 4). Mengatasi keterbatasan ruang, waktu dan ukuran. 5). Mengaktifkan siswa dalam belajar. 6). Mengefektifkan pemberian rangsangan untuk belajar (Tafonao, 2018). Dengan demikian penggunaan media pembelajaran dapat menunjang proses pembelajaran sehingga dapat mempermudah siswa dalam memahami dan mengingat materi yang disampaikan oleh guru secara cepat dan mudah.

Adapun media pembelajaran yang akan dikembangkan dalam penelitian ini adalah media permainan engklek. Permaianan engklek adalah permainan yang menggunakan media gambar persegi empat yang digambar di lantai ataupun di tanah dan dimainkan dengan cara melompati garis dengan satu kaki (Pratiwi \& Kristanto, 2014). Permainan engklek ini dimainkan dengan cara pemain pertama melempar genteng sebagai gacuk ke kotak pertama. Setelah itu, melompat kesemua kotak kecuali kotak yang dilempari gacuk secara berurutan dengan melompat menggunakan satu kaki kemudian kembali lagi untuk mengambil gacuk dengan satu tangan dan membawanya sampai keluar permainan (Kusumaningsih \& Suryanti, 2019). Permainan engklek merupakan sebuah permainan yang sudah dikenal luas oleh anak-anak.

Permainan engklek ini pernah dikembangkan sebagai media pembelajaran pada masa kelas rendah. Hal tersebut dapat dibuktikan dengan penelitian yang pernah dilakukan oleh Yusuf \& Adi (2020) yang mengungkapkan bahwa pengembangan media EFAS (Engklek Fun and Smart) dalam pembelajaran tematik pada Kelas 1 Sekolah Dasar menunjukkan hasil sangat baik. Hal tersebut ditunjukkan bahwa media yang dikembangkan menurut para ahli sangat layak digunakan karena media EFAS ini mampu mengintegrasikan mata pelajaran dengan sangat baik.

Adapun media engklek yang dikembangkan pada masa kelas tinggi dibuktikan dengan penelitian yang dilakukan oleh Buana \& Kasanah (2018) dengan mengembangkan model pembelajaran berbasis permainan engklek dalam upaya pengembangan karakter sejak usia dini 
unuk kelas IV SD menunjukkan hasil yang sangat valid yang dimana selama proses pembelajaran siswa lebih disiplin dan antusias mengikuti pembelajaran dari pengembangan produk yang sudah dihasilkan berupa sintaks model pembelajaran berbasis permainan engklek, jaring-jaring KD, RPP, media pembelajaran, LKS, dan penilaian autentik. Penelitian lainnya dilakukan oleh Nurhayati, Sulianto, \& Purnamasari (2017) mengungkapkan bahwa permainan engklek dapat digunakan sebagai media ketika menyampaikan materi pelajaran dan menarik perhatian siswa untuk belajar. Hal tersebut dapat dibuktikan dengan mengacu pada prosedur pengembangan permainan engklek sebagai media pembelajaran yang dikatakan layak pada materi energi dan perubahannya kelas $V$ sekolah dasar yang sudah dimodifikasi dan disesuaikan dengan kebutuhan yang ada di sekolah dasar. Dari beberapa hasil penelitian yang pernah dilakukan tersebut diketahui bahwa permainan engklek pernah digunakan sebagai media maupun model pembelajaran baik dimasa kelas rendah maupun tinggi. Akan tetapi disini peneliti belum pernah menemukan pengembangan media permainan engklek pada materi alat gerak manusia untuk kelas $V$.

Adapun hasil observasi di SDN Pemasah didapatkan informasi bahwa guru dalam menyampaikan materi pembelajaran umumnya masih menggunakan buku ajar tematik yang didampingi media gambar sebagai penunjang dan beberapa kali menggunakan multimedia seperti laptop dan alat pendukung yaitu proyektor yang terbatas jumlahnya. Dengan kondisi seperti ini, tentunya akan mengakibatkan siswa mengalami kesulitan dalam menerima materi, hal ini dapat dilihat dari kurang aktifnya siswa dalam mengikuti pembelajaran dan bahkan tidak jarang siswa bermain-main dengan teman sebangkunya pada saat pembelajaran sedang berlangsung. Bedasarkan uraian tersebut, penulis berkeinginan untuk mengembangkan media permainan engklek pada materi alat gerak manusia untuk siswa kelas $V$ (lima) Sekolah Dasar.

\section{METODE PENELITIAN}

Metode penelitian yang digunakan dalam penelitian ini adalah metode penelitian dan pengembangan dengan menggunakan model 4D yang merupakan singkatan dari Define, Design, Development and Dissemination. Penelitian ini dilaksanakan pada semester ganjil pada tahun ajaran 2020/2021 dengan subjek penelitian adalah 6 orang siswa kelas $V$ dari SDN Pemasah, dengan spesifikasi 2 siswa berkemampuan tinggi, 2 siswa berkemampuan sedang, dan 2 siswa berkemampuan rendah.

Media permainan engklek ini dirancang menggunakan Software Corel Draw dan dicetak menggunakan bahan banner berukuran $100 \mathrm{~cm} \times 230 \mathrm{~cm}$. Unsur pelengkap pada media permainan engklek yang telah dibuat adalah petunjuk permainan yang berukuran $30 \mathrm{~cm} \times 21 \mathrm{~cm}$, beberapa kartu soal dan kartu jawab yang terbuat dari kertas glossy dengan ukuran $10 \mathrm{~cm} \times 7 \mathrm{~cm}$ dan gacuk yang terbuat dari sisa-sisa genteng dengan ukuran $4 \mathrm{~cm} \times 3 \mathrm{~cm}$.

Adapun teknik pengumpulan data yang digunakan dalam penelitin ini adalah observasi, angket, dokumentasi, dan tes dalam bentuk uraian. Instrumen angket disebarkan kepada kepada ahli media, ahli materi, dan ahli pembelajaran untuk untuk mendapatkan hasil validasi dan angket yang disebarkan kepada siswa, digunakan untuk memperoleh data mengenai respon siswa. Dan untuk teknik analisis data dalam penilaian media permainan engklek ini menggunakan analisis deskriptif kualitatif dan analisis deskriptif kuantitatif dengan menggunakan skala likert. Skor hasil perhitungan konversi dengan skala lima dapat dilihat dalam Tabel 1.

Tabel 1. Konversi Data Kuantitatif ke Data Kualitatif dengan Skala 5

\begin{tabular}{cccc}
\hline Skala & Rumus & Rentang & Data Kualitatif \\
\hline 5 & $\mathrm{X}>\mathrm{Xi}+1,8 \mathrm{SBi}$ & $\mathrm{X}>4,2$ & Sangat Baik \\
4 & $\mathrm{Xi}+0,60 \mathrm{SBi}<\mathrm{X} \leq \mathrm{Xi}+1,8 \mathrm{SBi}$ & $3,4<\mathrm{X} \leq 4,2$ & Baik \\
3 & $\mathrm{Xi}-0,60 \mathrm{SBi}<\mathrm{X} \leq \mathrm{Xi}+0,60 \mathrm{SBi}$ & $2,6<\mathrm{X} \leq 3,4$ & Cukup \\
2 & $\mathrm{Xi}-0,80 \mathrm{SBi}<\mathrm{X} \leq \mathrm{Xi}+0,60 \mathrm{SBi}$ & $1,8<\mathrm{X} \leq 2,6$ & Kurang \\
1 & $\mathrm{X} \leq \mathrm{Xi}-1,8 \mathrm{SBi}$ & $X \leq 1,8$ & Sangat Kurang \\
\hline
\end{tabular}




\section{HASIL DAN PEMBAHASAN}

Hasil validasi dari ketiga validator memenuhi kategori valid dengan perolehan skor ratarata dari ahli media 4,27 dengan kriteria "sangat baik", dari ahli materi 3,7 dengan kriteria "baik", dan dari ahli pembelajaran 4,46 dengan kriteria "sangat baik". Dengan hasil rata-rata dari semua aspek penilaian tersebut media permainan engklek dapat dikategorikan layak untuk digunakan.

Tahap selanjutnya adalah uji coba terbatas yang dimana siswa diberikan tes untuk mengukur tingkat keefektifan media permainan engklek yang digunakan. Dari tes tersebut diperoleh skor rata-rata 8,17 dengan persentase ketuntasan 83\%. Data tersebut menunjukkan bahwa rata-rata hasil belajar siswa untuk muatan pelajaran IPA nilainya berada di atas KKM yang telah ditetapkan yaitu 66. Selain itu, respons keenam siswa pada saat uji coba terbatas menggunakan angket terhadap media pembelajaran yang dikembangkan memenuhi kategori positif karena memperoleh skor yaitu 4,47 dengan kriteria "sangat baik". Hal ini menunjukkan bahwa media permainan engklek dikategorikan layak untuk digunakan dalam proses pembelajaran.

Pada bagian ini, akan dibahas hasil penelitian terhadap media pembelajaran yang sudah dikembangkan. Media yang sudah dikembangkan tersebut berupa media permainan engklek dan unsur pelengkap lainnya seperti buku petunjuk permainan, beberapa kartu soal dan kartu jawab serta gacuk yang dimana dikembangkan berdasarkan kebutuhan guru dan siswa di SDN Pemasah untuk materi alat gerak manusia kelas V SD. Hal ini sejalan dengan penelitian yang dilakukan oleh Utami, Holisin, \& Mursyidah (2018) yang mengatakan bahwa media engklek yang digunakan juga terdiri dari bidang permainan, gacuk, kartu soal, dan lembar jawaban.

Proses pengembangan media pembelajaran berupa permainan yang memuat materi alat gerak manusia dikembangkan untuk membantu siswa dalam memahami materi alat gerak manusia dengan cara menggunakan media permainan. Untuk merancang media pembelajaran peneliti menggunakan model pengembangan 4D modifikasi Thiagarajan yang terdiri dari 4 tahapan yaitu pendefinisian (define), perancangan (design), pengembangan (develop), dan penyebaran (dessiminate). Tahap awal yang dilakukan dimulai dari analisis awal-akhir yang bertujuan untuk mengetahui dan menetapkan permasalahan yang dihadapi dalam proses pembelajaran. Selanjutnya adalah melakukan analisis siswa yang bertujuan untuk mengetahui karakteristik yang dimiliki oleh siswa melalui kegiatan observasi dan analisis konsep bertujuan untuk mengidentifikasi, merinci dan menyusun konsep-konsep utama yang akan dipelajari oleh siswa. Analisis tugas digunakan sebagai dasar untuk menyusun keterampilan-keterampilan utama untuk merancang media pembelajaran yang akan dikembangkan dan dilanjutkan dengan merumuskan tujuan-tujuan pembelajaran yang harus dicapai oleh siswa.

Tahap selanjutnya adalah perancangan atau penyiapan prototipe media pembelajaran yang terdiri atas 4 langkah yaitu: (1) Penyusunan tes untuk mengukur pencapaian hasil belajar siswa, (2) Pemilihan media yang sesuai dengan tujuan pembelajaran yang sudah ditetapkan, (3) Pemilihan format mencakup rancangan isi yang sudah disesuaikan dengan materi pembelajaran, (4) Rancangan awal dalam tahap ini berupa rancangan media dan unsur pelengkap pada media yang akan digunakan untuk memperoleh data yang dibutuhkan dalam proses pengembangan.

Tahapan selanjutnya adalah tahap pengembangan media pembelajaran yang terdiri atas beberapa proses yaitu: validasi ahli dan uji coba. Pada tahap ini diperoleh data yang berasal dari para validator dan subjek uji coba yang diolah menggunakan teknik analisis data yang telah dilakukan. Berdasarkan hasil validasi yang sudah dilakukan, diperoleh hasil bahwa media pembelajaran yang dikembangkan dapat dikategorikan valid karena dari ahli media diperoleh nilai rata-rata 4,27, dari ahli materi diperoleh nilai rata-rata 3,7 dan dari ahli pembelajaran diperoleh nilai rata-rata 4,46 .

Setelah media pembelajaran dikategorikan valid, maka tahap selanjutnya akan dilakukan uji coba terbatas namun harus diberikan perbaikan-perbaikan terlebih dahulu terhadap catatan yang diberikan validator pada setiap komponen yang divalidasi. Adapun catatan yang diberikan oleh ahli media hanya berkaitan dengan isi item instrumen angket seperti 1) penambahan item tata letak pemberian nomor pada masing-masing kolom tersusun dengan runtut, 2) antara 
gambar dan keterangan sesuai, 3) penjelasan informasi tertulis secara runtut, dan 4) Lembar instrumen dilengkapi dengan rumus penghitungan skor nilai.

Dari ahli materi diberikan beberapa catatan seperti: 1) Media permainan engklek dilengkapi dengan tujuan pembelajaran yang jelas dan disesuaikan dengan indikator pencapaian kompetensi yang terdapat pada kisi-kisi, 2) Masing-masing poin materi pada kolom media 1-8 dilengkapi dengan materi yang ringkas sesuai dengan indikator pencapaian kompetensi dan tujuan pembelajaran yang ingin dicapai, 3) Jumlah kartu soal sesuai dengan indikator pencapaian kompetensi dan tujuan pembelajaran yang ingin dicapai, 4) Isi dan jumlah kartu soal sesuai dengan kisi-kisi penulisan soal yang telah dibuat, dan 5) Sesuaikan dengan pembelajaran tematik di SD yang mengacu pada Permendikbud No. 37 Tahun 2018 KI-KD dan disesuaikan dengan buku pembelajaran (baik buku guru maupun buku siswa) sehingga media yang dikembangkan menyajikan beberapa konsep muatan pembelajaran dalam suatu proses pembelajaran.

Media permainan engklek yang dikembangkan masih memiliki beberapa kekurangan. Hal ini sejalan dengan hasil penelitian Munawaroh (2017) bahwa media permainan engklek yang dikembangkan juga memiliki kekurangan setelah melakukan proses penilaian oleh pakar atau ahli. Akan tetapi revisi tidak sampai merubah sintaks media. Lebih lanjut saran yang ada lebih cenderung pada kelengkapan yang mendukung pengembangan media tersebut. Dan yang terakhir media pembelajaran yang dikembangkan tidak mendapatkan catatan atau revisi dari ahli pembelajaran.

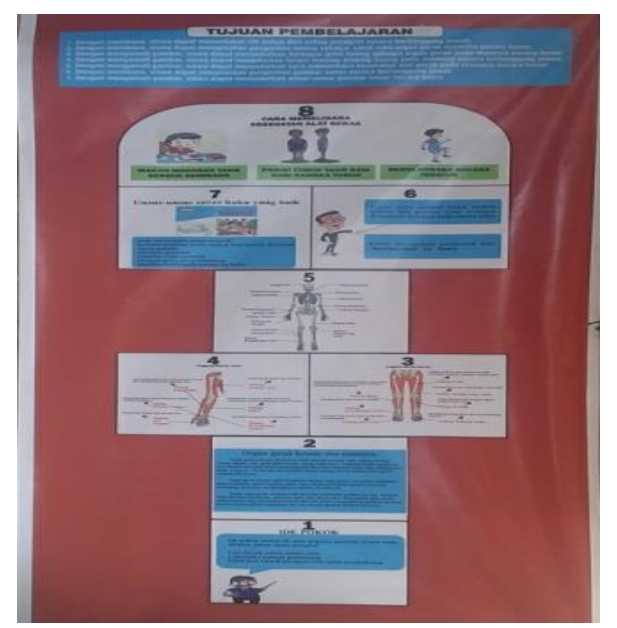

Gambar 1. Hasil pengembangan media permainan engklek

Setelah media selesai divalidasi, selanjutnya akan dilakukan uji coba menggunakan tes dan lembar angket kepada 6 siswa yang telah dipilih. Kriteria keefektifan media pembelajaran yang dikembangkan terpenuhi jika siswa dapat mencapai ketuntasan lebih besar atau sama dengan (80\%) artinya dari 6 siswa minimal 5 orang siswa yang harus mencapai batas KKM yang ditetapkan yaitu 66. Berdasarkan uji coba yang telah dilakukan, sebanyak 5 siswa atau sekitar $83 \%$ siswa yang mencapai ketuntasan. Data tersebut menunjukkan bahwa rata-rata hasil belajar siswa untuk muatan pelajaran IPA nilainya berada di atas KKM. Sehingga dapat diketahui bahwa siswa mampu menyerap pelajaran dengan menggunakan media permainan engklek yang dikembangkan. Hal tersebut sesuai dengan yang dikemukakan oleh Yamasari (dalam Lestari, 2017) media permainan engklek dapat dikatakan efektif jika lebih besar atau sama dengan $80 \%$ dari seluruh subjek uji coba yang mencapai skor tuntas. Hal ini juga sejalan dengan penelitian yang dilakukan oleh Ismah \& Dwitama (2018) yang memiliki kesamaan dalam menggunakan tes untuk menilai keefektifan media matematika engklek yang telah dikembangkan jika hasil belajar siswa mencapai $\geq 75 \%$ KKM.

Keenam siswa tersebut selanjutnya akan diberikan angket yang mengacu pada skala Likert dengan menggunakan 5 pilihan untuk mengetahui respons siswa terhadap media yang telah 
dikembangkan. Hasil akhir yang diperoleh dari uji coba menggunakan angket ini adalah 4,47 yang masuk dalam kategori sangat baik. Hasil penelitian tersebut sesuai dengan yang diungkapkan oleh Emda (2011) bahwa penggunaan media pembelajaran yang baik dan tepat akan memberikan keuntungan bagi guru dan siswa karena dapat membantu kelancaran proses belajar mengajar serta akan sangat bermanfaat bagi siswa karena sangat membantu dalam meningkatkan pengenalan dan pemahaman terhadap materi yang diajarkan.

Berdasarkan paparan dan gambar hasil pengembangan media di atas dapat disimpulkan bahwa, media permainan engklek yang dikembangkan merupakan media pembelajaran yang valid karena dari hasil penilaian keseluruhan aspek secara umum mendapatkan kriteria sangat baik dari tiga validator. Hasil data yang diperoleh dari pemberian soal tes dengan hasil sekitar $83 \%$ siswa yang mencapai ketuntasan dan rata-rata hasil angket yang diperoleh mendapat skor 4,47 menunjukkan bahwa siswa memberikan respons dan tanggapan yang rata-rata positif terhadap media permainan engklek yang dikembangkan. Hasil penelitian tersebut juga sesuai dengan hasil penelitian sebelumnya dari Wiranti \& Mawarti (2018:72-73) yang menyatakan bahwa media permainan engklek mendapat respons yang positif, dimana melalui permainan engklek siswa merasa mudah dalam melakukan gerakan motorik kasar, merasa senang dalam pembelajaran, merasa senang bermain berkelompok, dan ingin melakukan permainan engklek lagi. Setelah media permainan engklek dikategorikan valid, maka selanjutnya media tersebut akan disebarkan terbatas hanya dilakukan saat uji coba media di SDN Pemasah.

\section{KESIMPULAN}

Pengembangan media permaianan engklek dilakukan menggunakan model 4D yang terdiri dari 4 tahapan yaitu pendefinisian (define), perancangan (design), pengembangan (develop), dan penyebaran (dessiminate). uji validasi dan uji terbatas. Media permainan engklek yang dikembangkan memenuhi kategori valid dari ketiga validator dengan perolehan skor ratarata dari ahli media 4,27, dari ahli materi 3,7, dan dari ahli pembelajaran 4,46. Dengan hasil rata-rata dari semua aspek penilaian tersebut media permainan engklek dapat dikategorikan layak untuk digunakan. Respons siswa yang diberikan tes dengan skor rata-rata hasil tes adalah 8,17 dengan persentase ketuntasan $83 \%$. Respons keenam siswa terhadap media pembelajaran yang dikembangkan memenuhi kategori positif dengan perolehan nilai rata-rata pada saat uji coba terbatas yaitu 4,47 . Hal ini menunjukkan bahwa media permainan engklek dikategorikan layak untuk digunakan dalam proses pembelajaran.

\section{DAFTAR PUSTAKA}

Buana, V. G., \& Kasanah, S. U. (2018). Model Pembelajaran Berbasis Permainan Engklek dalam Upaya Pengembagan Karakter Sejak Usia Dini. Jurnal Riset dan Konseptual, 3, 501.

Eko Putro Widoyoko. (2009). Evaluasi Program Pembelajaran. Yogyakarta:Diva Press

Emda, A. (2011). Pemanfaatan Media dalam Pembelajaran Biologi di Sekolah. Jurnal Ilmiah DIDAKTIKA, XII, 161.

Ermiana, I., Witono, H. A., \& Khair, B. N. (2019). Pengembangan media berdasar komputer (CBI) untuk meningkatkan hasil belajar IPA siswa kelas III di SDN 12 Ampenan. Seminar Nasional Pagelaran Pendidikan Dasar Nasional_(PPDN), 297.

Ismah, \& Dwitama, A. T. (2018). Pengembangan media pembelajaran matematika dengan konsep permainan engklek (matlek). Seminar nasional pendidikan era revolusi, 161.

Jalinus, N., \& Ambiyar. (2016). Media dan sumber pembelajaran. Jakarta: Kencana.

Japar, M., Fadhillah, D. N., \& H.P, G. L. (2019). Media dan Teknologi Pembelajaran PPKN. Surabaya: CV.Jakad Publishing Surabaya.

Kusumaningsih, A., \& Suryanti. (2019). Efektivitas penerapan permainan tradisional engklek terhadap hasil belajar siswa kelas IV di SDN Lidah Wetan II/462 Surabaya.JPGSD, 07, 32183227.

Lefudin. (2017). Belajar dan pembelajaran. Yogyakarta: CV BUDI UTAMA.

Lestari, P. (2017). Pengembangan alat peraga ular tangga logaritma untuk siswa SMK.Skripsi. Universitas Muhammadiyah Purworejo. 
Munawaroh, H. (2017). Pengembangan model pembelajaran dengan permainan tradisional engklek sebagai sarana stimulasi perkembangan anak usia dini. Jurnal Pendidikan Anak Usia Dini, 1 (2), 94.

Pratiwi, Y., \& Kristanto, M. (2014). Upaya meningkatkan kemampuan motorik kasar (keseimbangan tubuh) anak melalui permainan tradisional engklek di Kelompok B Tunas Rimba II Tahun Ajaran 2014/2015. Jurnal Penelitian PAUDIA, 28.

Tafonao, T. (2018). Peranan Media Pembelajaran dalam Meningkatkan Minat Belajar Siswa. Jurnal Komunikasi Pendidikan, 2, 105.

Utami, N. I., Holisisn, I., \& Mursyidah, H. (2018). Pengembangan media pembelajaran engklek geometri untuk melestarikan permainan tradisional. Jurnal ilmiah pendidikan MIPA, 8, 222.

Wiranti, D. A., \& Mawarti, D. A. (2018). Keefektifan permainan engklek dalam mengembangkan kemampuan motorik kasar anak usia dini. Jurnal Ilmiah Kependidikan, 9, 72-73.

Yusuf, \& Adi, D. (2020). Pengembangan Media EFAS (Engklek Fun and Smart) dalam Pembelajaran Tematik pada Kelas 1 Sekolah Dasar. Skripsi. Universitas Muhammadiyah Malang 